\title{
The Use of Earth-to-Air and Air-to-Air Heat Exchangers for Different Italian Climates
}

\author{
Diana D'Agostino, Concetta Marino and Francesco Minichiello * \\ DII - Department of Industrial Engineering (ETEC division), University of Naples Federico II, 80 \\ Piazzale Tecchio, 80125 Napoli, Italy \\ Email:minichie@unina.it
}

\begin{abstract}
Nowadays, it is very important the use of different technologies that reduce the energy consumption.

This paper investigates the energy saving obtainable by using air conditioning systems provided with suitable earth-to-air (EAHX) and/or air-to-air (AAHX) heat exchangers, for two different Italian climates: Palermo, a city of Southern Italy characterized by hot summers and mild winters, and Milan, a city of Northern Italy characterized by hot summers and cold winters. A case study is analyzed by means of dynamic building energy performance software, with reference to the same designed office building with or without the two types of heat exchangers. The seasonal results show that in winter the AAHX reduces the energy requirement more than the EAHX, while in summer the EAHX is more effective. Yearly results show that the use of the EAHX is preferable in mild or hot climates.

Moreover, basing on the seasonal results, the two technologies are combined (using the AAHX in winter and the EAHX in summer). The results show that the coupling of the two heat exchangers is more convenient for Milan (saving up to $74 \%$ ) than for Palermo (59\%).

Finally, the $\mathrm{CO}_{2}$ emission reductions and discounted payback periods for the two technologies are evaluated.
\end{abstract}

Keywords: Air-to-air, Building energy performance software, Discounted payback, Earth-to-air, Heat exchangers.

\section{INTRODUCTION}

Nowadays all the constructions and the related systems should be very energy performing.

In this paper, two technologies, the Earth-to-Air Heat Exchanger (EAHX) and Air-to-Air Heat Exchanger (AAHX), are analyzed and compared from the energy, environmental and economic point of view.

In order to reduce the high energy demand connected to the air conditioning systems, the heat recovery is one of the few components able to both meet the need of outside air changes and limit the energy waste.

The most important kinds of AAHX are two: plate type or rotary type. The first one allows transferring thermal energy between two airflows under the action of a temperature difference. It is possible to exchange both sensible heat (only when the plates are made of a non-porous material, such as aluminum) and latent heat, when the material of the plates is porous. A distinction is useful between heat recovery and heat recovery groups; the latter ones are constituted by the recuperator, but also by a series of accessories such as filters, preheating devices, dampers, control devices, which are assembled into a container having connecting flanges at the main ducts.
The material of the plates is commonly aluminum, known for its corrosion resistance characteristics, ease of embodiment and duration. For more corrosive environments, aluminum can be protected with acrylic paint; while in the presence of high temperatures (over $200{ }^{\circ} \mathrm{C}$ ) and where the cost does not represent a key factor, stainless steel is used. In addition, there is the possibility of providing the by-pass control of the heat recovery unit, which has the purpose of optimizing the use of the component. In this way, the AAHX is used only when convenient (when there is an appropriate difference in temperature between the outside and the exhaust air). To achieve good results, the by-pass should be used according to a suitable control of the inlet/outlet air temperature.

This technology is widely used for energy improvement of the buildings, especially when energy savings without expensive interventions are required.

Several authors analyzed the AAHX to find the energy savings obtainable when it is coupled to a mechanical ventilation system. The purpose of [1] is the evaluation of the energy performance of a system made up of mechanical ventilation and AAHX in a residential building in Latvnia (North-East Europe). They found a heating percentage energy saving of about $60 \%$ compared to another similar 
building characterized by only natural ventilation. In [2], the use of a heat exchanger in a detached house in Sweden was investigated, and the reduction of thermal losses was evaluated, as well as the mitigation of indoor radon problem by using this technology. The results present a percentage reduction of ventilation energy losses of about $74 \%$ compared to the case without heat recovery.

It is worth mentioning that the AAHX is an easy solution to reduce energy requirements mainly in existing buildings, originally designed only with a natural ventilation system or with mechanical ventilation $[3,4]$.

The EAHX is a technology that exploits the capability of the ground as energy storage, through a system of earthed pipes laid horizontally. Indeed, in summer the ground presents a temperature lower than air, while in winter it could have, in some hours/days, a temperature higher than air (Figure $1[5]$ ).

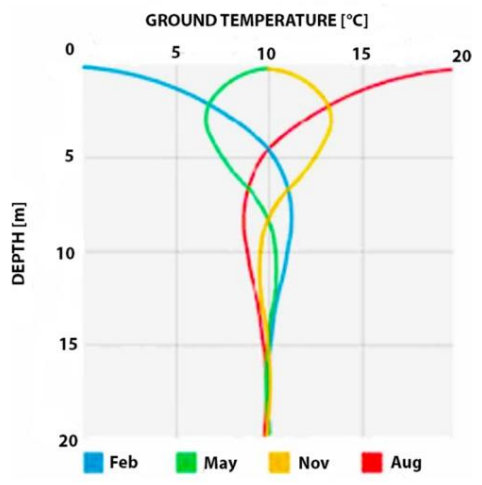

Figure 1. Ground temperature as a function of depth [5]

As evidenced by other authors [6], different types of ground or different materials, length and diameter of the pipes can influence the performance and the energy savings related to the EAHX. Several studies have been conducted on this type of exchangers, such as those reported in [7], focused on the effects of an air-ground heat exchanger installed at the University of Ioannina, a Greek town with cold winter and hot and humid summer. In this case, the heat exchanger consists of 5 ducts installed at a depth of $2 \mathrm{~m}, 30 \mathrm{~m}$ long and having a diameter equal to $0.15 \mathrm{~m}$. The air velocity is $3 \mathrm{~m} \cdot \mathrm{s}^{-1}$. The measurements have shown that the air temperature, with maximum outside levels of about $35{ }^{\circ} \mathrm{C}$, decreased to $10{ }^{\circ} \mathrm{C}$ at outlet ducts. Even other German experiences [8] show that this type of heat exchangers is more efficient in summer than in winter. Considering an administrative building in Esslingen (Germany), 9\% of the energy required for heating is covered by the earth-to-air heat exchanger, while the reduction of summer energy demand is greater (about 23\%).

Other authors investigated a new cooling technique using phase change materials for energy saving in summer [9].

Although there are research works that assess the reduction of primary energy or the reduction of thermal losses by using the above reported kinds of heat exchangers, few results are available on the comparison of the two technologies for different climatic zones.

In this paper, the authors perform an energetic, environmental and economic comparison between these two types of heat exchanger, by means of a dynamic simulation software, for two different Italian climates. A case study referred to a designed new office building is analyzed, and the two heat exchangers are separately inserted in the related air conditioning system. Successively, the case of using the two coupled technologies in the same HVAC system is analyzed. Finally, an energetic-economic analysis is carried out to obtain the discounted payback period for the two kinds of heat recovery, with and without an incentive of $20 \%$.

\section{USED METHODOLOGY AND CASE STUDY}

The analysis is performed by using two dynamic building energy performance simulation software. The software DesignBuilder [10] is used to model the building envelope, while the software EnergyPlus [11] to set up the HVAC system and to launch the dynamic simulations.

Energy Plus was validated through measured data in Europe [12]; moreover, several validation tests are available for HVAC systems [13] and for building envelope [14].

Other codes were used in [15]. This study investigates the energy demand of a residential building, and the case is validated through energy consumption real data.

International Weather for Energy Calculation (IWEC) climatic data are used [16], because of their authoritativeness.

The case study is an office building simulated in two different cities of Italy, i.e. Palermo (Southern Italy, hot summers and mild winters) and Milan (Northern Italy, continental climate with hot summers accentuated by the heat island effect due to the great density of the buildings in the city, and cold winters).

In the Tables 1 and 2 , the geographic and climatic parameters of Palermo and Milan are reported.

Table 1. Main geographic and climatic characteristics of Palermo [16]

\begin{tabular}{|l|l|l|}
\hline Geographic or climatic parameter & Unit & Value \\
\hline Latitude & {$\left[{ }^{\circ}\right]$} & $38^{\circ} 63^{\prime} 43^{\prime} 56 \mathrm{~N}$ \\
\hline Longitude & {$\left[{ }^{\circ}\right]$} & $13^{\circ} 20^{\prime} 111^{\prime} 76 \mathrm{E}$ \\
\hline Maximum dry bulb temperature & {$\left[{ }^{\circ} \mathrm{C}\right]$} & $34.0(17 \mathrm{Jul})$ \\
\hline Minimum dry bulb temperature & {$\left[{ }^{\circ} \mathrm{C}\right]$} & $4.8(3 \mathrm{Feb})$ \\
\hline $\begin{array}{l}\text { HDD Heating Degrees-day } \\
\left.\text { (referred to } 18.3^{\circ} \mathrm{C}\right)\end{array}$ & {$[\mathrm{K} \cdot \mathrm{day}]$} & 802 \\
\hline $\begin{array}{l}\text { CDD Cooling Degrees-day } \\
\text { (referred to18.3 }{ }^{\circ} \mathrm{C} \text { ) }\end{array}$ & {$[\mathrm{K} \cdot \mathrm{day}]$} & 1,002 \\
\hline $\begin{array}{l}\text { Maximum average direct normal } \\
\text { solar radiation }\end{array}$ & {$\left[\mathrm{Wh} \cdot \mathrm{m}^{-2}\right]$} & $6,733(\mathrm{Jul})$ \\
\hline Winter design outdoor temperature & {$\left[{ }^{\circ} \mathrm{C}\right]$} & 6.8 \\
\hline Cooling design outdoor temperature & {$\left[{ }^{\circ} \mathrm{C}\right]$} & 33.5 \\
\hline
\end{tabular}

Table 2. Main geographic and climatic characteristics of Milan [16]

\begin{tabular}{|l|l|l|}
\hline Geographic or climatic parameter & Unit & Value \\
\hline Latitude & {$\left[{ }^{\circ}\right]$} & $45^{\circ} 28^{\prime} 38^{\prime \prime} 28 \mathrm{~N}$ \\
\hline Longitude & {$\left[{ }^{\circ}\right]$} & $09^{\circ} 10^{\prime} 53^{\prime \prime} 40 \mathrm{E}$ \\
\hline Maximum dry bulb temperature & {$\left[{ }^{\circ} \mathrm{C}\right]$} & $32.6(24 \mathrm{Jul})$ \\
\hline Minimum dry bulb temperature & {$\left[{ }^{\circ} \mathrm{C}\right]$} & $-11(30 \mathrm{Jan})$ \\
\hline $\begin{array}{l}\text { HDD Heating Degrees-day } \\
\left.\text { (referred to } 18.3^{\circ} \mathrm{C}\right)\end{array}$ & {$[\mathrm{K} \cdot \mathrm{day}]$} & 372 \\
\hline $\begin{array}{l}\text { CDD Cooling Degrees-day } \\
\left.\text { (referred to } 18.3^{\circ} \mathrm{C}\right)\end{array}$ & {$[\mathrm{K} \cdot \mathrm{day}]$} & 2,654 \\
\hline $\begin{array}{l}\text { Maximum average direct normal } \\
\text { solar radiation }\end{array}$ & {$\left[\mathrm{Wh} \cdot \mathrm{m}^{-2}\right]$} & $6,146(\mathrm{Jul})$ \\
\hline Winter design outdoor temperature & {$\left[{ }^{\circ} \mathrm{C}\right]$} & -3.7 \\
\hline Cooling design outdoor temperature & {$\left[{ }^{\circ} \mathrm{C}\right]$} & 31 \\
\hline
\end{tabular}


The building (Figure 2) has a floor area of $410 \mathrm{~m}^{2}$ and stands on two levels $\left(410 \times 2=820 \mathrm{~m}^{2}\right)$ plus a basement, not air-conditioned, used as a garage. The shape of the building is the same for the two cities, but the thermal characteristics are different (chosen based on the legislation for each climatic zone). In the Table 3, the U-values of the building envelope components for Palermo and Milan are shown.

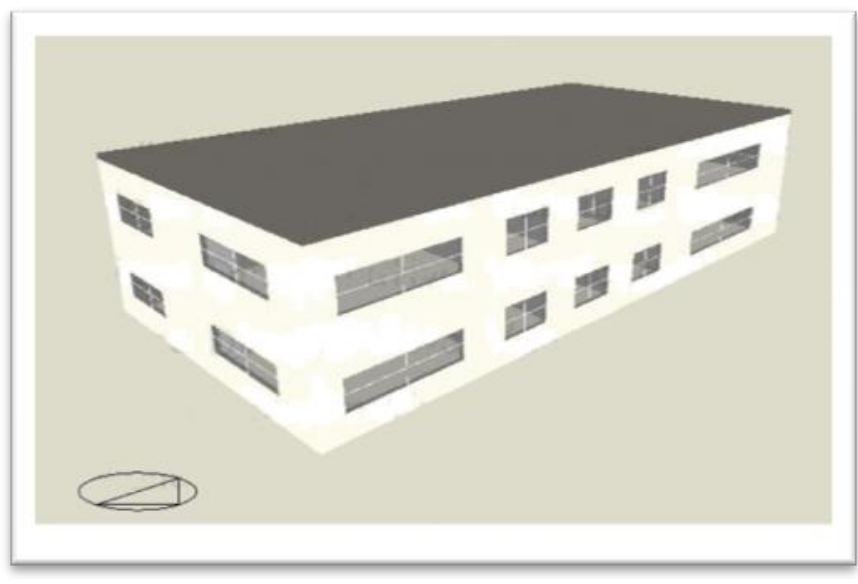

Figure 2. Tridimensional model of the case study building

Table 3. U-values of the building envelope components

\begin{tabular}{|l|l|l|}
\hline & $\begin{array}{l}\mathrm{U}-\text { Value for } \\
\text { Palermo }\left[\mathrm{W} \cdot \mathrm{m}^{-2} \cdot \mathrm{K}^{-1}\right]\end{array}$ & $\begin{array}{l}\mathrm{U} \text {-Value for } \\
\text { Milan }\left[\mathrm{W} \cdot \mathrm{m}^{-2} \cdot \mathrm{K}^{-1}\right]\end{array}$ \\
\hline Walls & 0.260 & 0.240 \\
\hline Roof & 0.150 & 0.130 \\
\hline Slab on the ground & 0.350 & 0.240 \\
\hline Windows & 1.50 & 1.29 \\
\hline
\end{tabular}

The HVAC system is based on fan-coils and primary air; for some performed simulations, the Air Handling Unit (AHU) is provided with an air-to-air heat exchanger or an earth-to-air heat exchanger. These two technologies pre-heat the external air in winter and cool it in summer. Thus, both the energy demand and equivalent $\mathrm{CO}_{2}$ emissions are lowered. Design indoor temperatures are $20{ }^{\circ} \mathrm{C}$ for winter and $26^{\circ} \mathrm{C}$ for summer.

With reference to the AAHX, a static type of recovery with partition wall was considered, then belonging to the category Ia [17]. This category allows recovering both the sensible and latent heat. In fact, when the walls of the exchanger are colder than the exhaust air dew-point temperature, the vapor within this airflow condenses and is transferred to the ventilation airflow in input. The parameters used for the AAHX are the following:

- Thermal sensible load: effectiveness equal to $75 \%$ at rated capacity of $100 \%$ (for both heating and cooling) and to $70 \%$ for flow rate of $75 \%$;

- Thermal latent load: effectiveness equal to $70 \%$ at rated capacity of $100 \%$ (for both heating and cooling) and to $65 \%$ for flow rate of $75 \%$.

Regarding the EAHX, EnergyPlus can simulate its energy behavior and the modeling of this component requires the determination of different parameters. Some of the main parameters are (in parenthesis the chosen value or type):

1. temperature difference between the internal and external environment under which the heat exchanger is turned off $\left(0^{\circ} \mathrm{C}\right)$

2. air flow velocity $\left(2 \mathrm{~m}^{-1}\right)$;
3. pressure of the fan $(50 \mathrm{~Pa})$;

4. radius, thickness and length of the duct $(0.10 \mathrm{~m}, 0.005 \mathrm{~m}$, $100 \mathrm{~m}$ );

5. duct material, metallic or plastic (PVC, thermal conductivity of $\left.0.16 \mathrm{~W} \cdot \mathrm{m}^{-1} \cdot \mathrm{K}^{-1}\right)$;

6. depth (-4 $\mathrm{m}$ with respect to the ground level);

7. type of terrain (tender rock);

8. average soil temperature $\left(17.8^{\circ} \mathrm{C}\right.$ for Palermo, $14.4{ }^{\circ} \mathrm{C}$ for Milan).

The EAHX is located upstream of primary air handling unit, in order to pre-heat (in winter conditions) and pre-cool (in summer season) the external air. Thus, the energy demand for heating/cooling and $\mathrm{CO}_{2}$ equivalent emissions can be reduced. The exchanger, as seen previously, exploits the ability of soil to accumulate thermal energy through a system of ducts installed in the ground horizontally.

Once the characteristics of the building envelope and the HVAC system are defined, the seasonal and the yearly energy requirements are evaluated when using the AAHX or the EAHX inserted in the primary air handling unit. All the results are compared with a base case, i.e. a building with the same thermal characteristics and HVAC system (fan-coils and primary air), but without AAHX/EAHX heat exchangers. The results show interesting energy savings related to the use of the two analyzed heat exchangers. Finally, basing on the seasonal results, the two technologies are coupled.

In all the considered cases, a suitable air-to-water heat pump is considered as heating and cooling generator (SCOP of 3.1 for Palermo, 2.8 for Milan; SEER of 3.0 for Palermo, 3.1 for Milan).

\section{RESULTS ON ENERGY AND ENVIRONMENTAL ANALYSIS}

In this section, the energy requirements and the $\mathrm{CO}_{2}$ emissions are evaluated by means of the dynamic simulation, and compared for the following cases: reference case without any heat exchanger; the case with the AAHX; the case with EAHX. All these configurations are evaluated for both Palermo and Milan, considering the electric energy requirements for: heating (generator), cooling (generator), auxiliary (both heating and cooling) and yearly demand (heating + cooling + auxiliary).

Once evaluated the seasonal performance of the two technologies, a further annual comparison is performed, combining the two technologies. Their alternating operation depends on the seasonal results (each heat exchanger is activated only in the season for which it presents the best energy results).

\subsection{Seasonal energy results when using the AAHX}

In the Figures 3 and 4, the annual electric energy requirements of the $\mathrm{HVAC}$ system are reported in $\mathrm{kWh}_{\mathrm{el}}$ per unitary floor surface, with reference to the cases above described. In addition, the percentage savings compared to the reference case are shown.

Regarding the use of the AAHX, in winter it leads for Palermo to an energy saving of even $97 \%$ compared to the case with only AHU and fan-coils ( $88 \%$ for Milan), while in summer the energy reduction is only of $2 \%$ ( $0 \%$ for Milan).

It means that for hot climates, such as Palermo, the winter energy demand is so low that it is almost entirely offset by 
the air-to-air heat recovery. In fact, the temperature difference between outdoor and indoor air can be dramatically reduced by only the AAHX.

Regardless of the type of climate, it can be noted however that the energy performance of the air-to-air heat exchanger is drastically higher in winter than in summer.

\subsection{Seasonal energy results when using the EAHX}

In addition, the energy requirements for the case with the EAHX are reported in the Figures 3 and 4, as well as the percentage savings compared to the reference case.

The results show that in winter the EAHX leads for Palermo to an energy saving of only $6 \%$ compared to the base case without any heat recovery (5\% for Milan), while in summer the energy reduction is equal to $46 \%$ (49\% for Milan). Therefore, unlike the AAHX, the EAHX allows energy savings far greater in summer than in winter, and this occurs thanks to the temperature of the soil in simmer, lower than the outside air temperature.

\subsection{Yearly energy results when coupling the AAHX and EAHX}

Considering the seasonal results (sections 3.1 and 3.2), it can say that the highest savings occur in winter when using the AAHX, while in summer the EAHX is more efficient. Moreover, the comparisons between the two technologies separately and the base case, lead to state that the use of the AAHX for both heating and cooling is more efficient for continental climates such as Milan (yearly saving of 64\%) than for hot climates such as Palermo (yearly saving of 28\%). On the contrary, the EAHX is more efficient in Palermo (yearly saving of 30\%) than in Milan (yearly saving of 13\%).

Therefore, it was decided to combine the two technologies, using only the AAHX for winter heating while only the EAHX for summer cooling, for both the climates. It means that the building that has a HVAC system without any heat recovery is compared with another that has the same facilities of the base case, plus the AAHX for heating and the EAHX for cooling.

As can be seen in the Figures 3 and 4, the histograms show that the yearly energy saving is 59\% for Palermo and $74 \%$ for Milan. This result is very interesting mainly for Milan, for the following reasons: it shows that in a continental climate with cold winters and hot summers, the coupling of the two technologies leads to a relevant saving (74\%); considering the significant yearly energy requirements (higher than for Palermo), a considerable absolute energy saving is obtained.

\subsection{Environmental analysis: reduction of $\mathrm{CO}_{2}$ emissions}

The carbon dioxide emissions are calculated for Milan and Palermo, in $\mathrm{kg}_{\mathrm{CO} 2 \text {-eq }}$ per unitary floor surface (Tables 4 and 5). An equivalent $\mathrm{CO}_{2}$ emission factor of $0.708 \mathrm{t}_{\mathrm{CO} 2-\mathrm{eq}} / \mathrm{MWh}_{\mathrm{el}}$ is considered for the environmental analysis. In the Figure 5, the emissions for Milan are reported, as well as the percentage reductions with respect to the reference case without heat recovery. Results similar to the energetic results are obtained.

The coupling of the two heat exchangers leads to:

- for Milan, the greatest reduction of yearly emissions $\left(20 \mathrm{~kg}_{\mathrm{CO} 2 \text {-eq }} \cdot \mathrm{m}^{-2}\right.$, i.e. $74 \%$ ) compared to the base case;
- for Palermo, a minor but anyway relevant reduction of yearly emissions ( $9 \mathrm{~kg}_{\mathrm{CO} 2 \text {-eq }} \mathrm{m}^{-2}$, i.e. $59 \%$ ) compared to the base case.

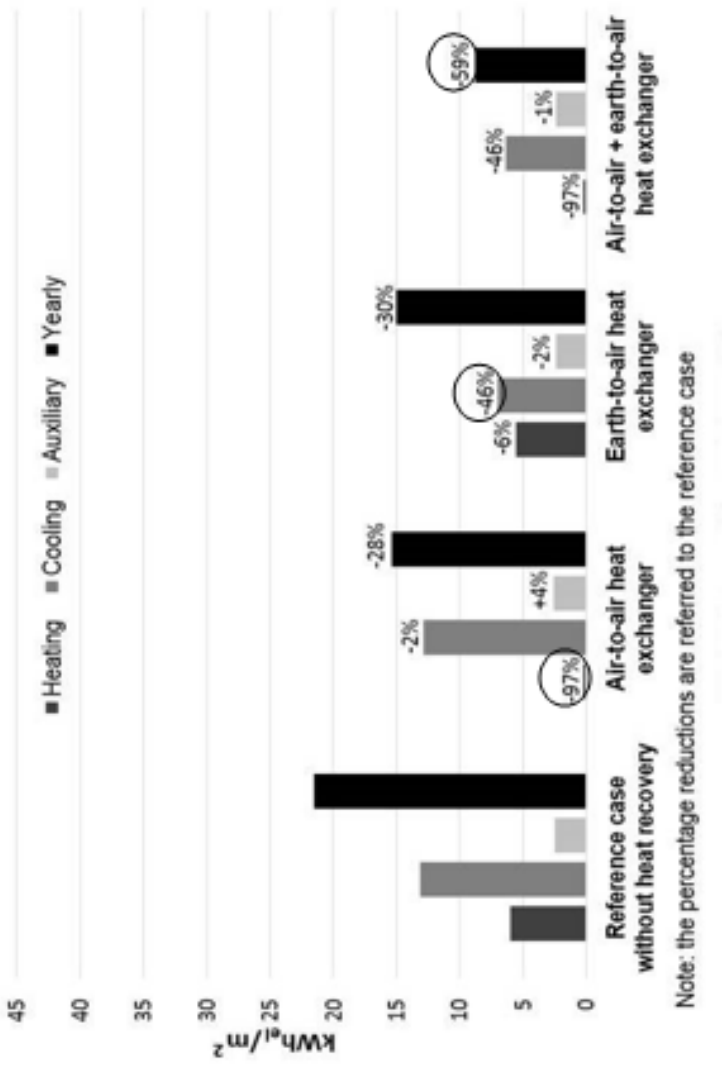

Figure 3. Annual electric energy required per unitary floor surface and percentage energy savings for Palermo

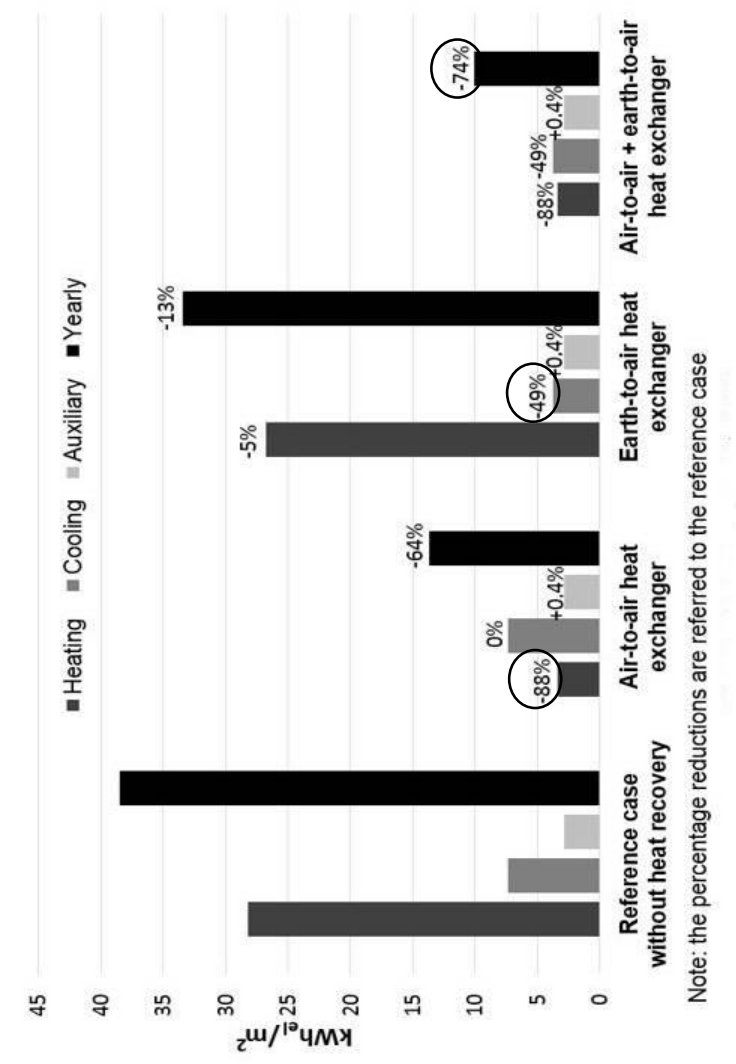

Figure 4. Annual electric energy required per unitary floor surface and percentage energy savings for Milan 


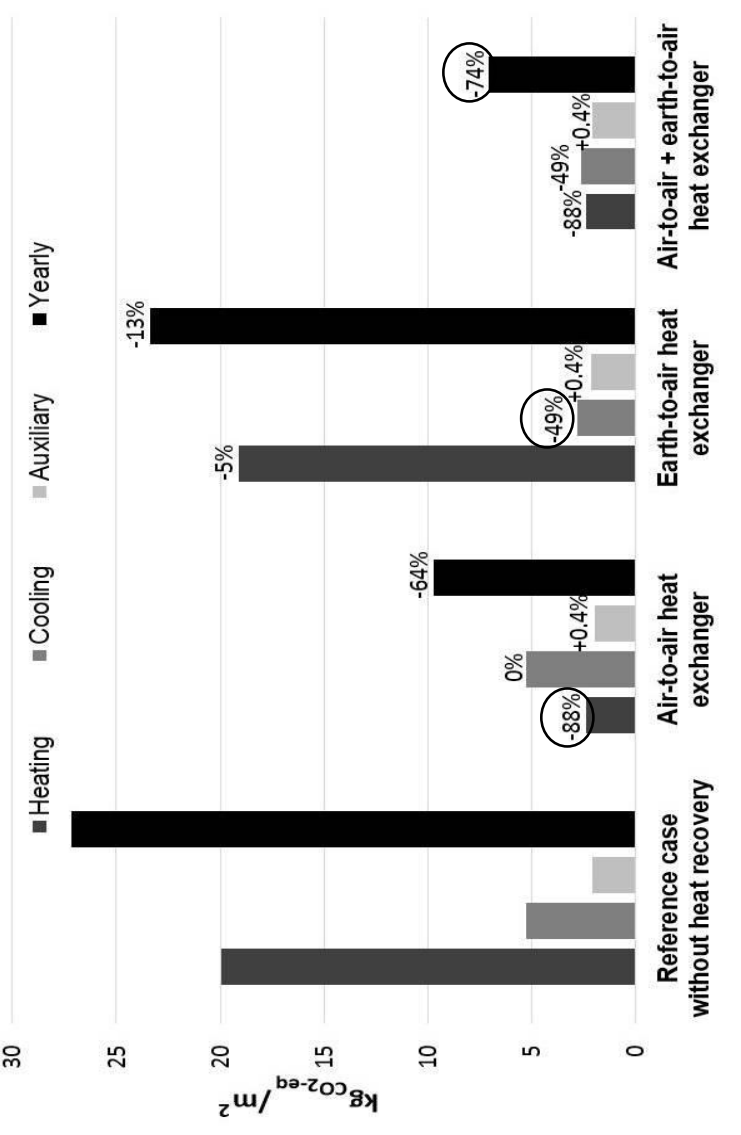

Figure 5. Equivalent $\mathrm{CO}_{2}$ annual emissions for Milan

Table 4. Annual emissions for Palermo $\left(\mathrm{kg}_{\mathrm{CO} 2-\mathrm{eq}} \cdot \mathrm{m}^{-2}\right)$

\begin{tabular}{|c|c|c|c|c|}
\hline & $\begin{array}{c}\text { Reference } \\
\text { case }\end{array}$ & AAHX & EAHX & $\begin{array}{c}\text { AAHX + } \\
\text { EAHX }\end{array}$ \\
\hline Heating & 4.2 & 0.14 & 4.2 & 0.14 \\
\hline Cooling & 9.3 & 9.1 & 4.96 & 4.5 \\
\hline Auxiliary & 1.8 & 1.8 & 1.4 & 1.7 \\
\hline Yearly & 15.2 & 10.9 & 10.6 & 6.2 \\
\hline
\end{tabular}

Table 5. Annual emissions for Milan $\left(\mathrm{kg}_{\mathrm{CO} 2-\mathrm{eq}} \cdot \mathrm{m}^{-2}\right)$

\begin{tabular}{|c|c|c|c|c|}
\hline & $\begin{array}{c}\text { Reference } \\
\text { case }\end{array}$ & AAHX & EAHX & $\begin{array}{c}\text { AAHX + } \\
\text { EAHX }\end{array}$ \\
\hline Heating & 19.97 & 2.4 & 19.1 & 2.4 \\
\hline Cooling & 5.2 & 5.2 & 2.8 & 2.6 \\
\hline Auxiliary & 2.05 & 1.98 & 2.1 & 2.05 \\
\hline Yearly & 27.2 & 9.7 & 23.4 & 7.08 \\
\hline
\end{tabular}

\section{ENERGETIC-ECONOMIC ANALYSIS}

An energetic-economic analysis is performed for each of the two analyzed technologies.

For the evaluation of the cost of AAHX, a market survey of the most common producers of exchangers in Italy was made. Regarding labor cost, the hourly cost was derived for Palermo and Milan from [18,19]. Moreover, ordinary maintenance fees $(1.5 \%$ of [AAHX cost + labor] $)$ are assumed once a year and extraordinary maintenance fees $(5 \%)$ once every three years.

The costs for the AAHX are reported in the Table 6.
Table 6. Costs of the AAHX for Palermo and Milan

\begin{tabular}{|l|l|l|}
\hline & {$[€]$} & {$[\%]$} \\
\hline AAHX (about $\left.5000 \mathrm{~m}^{3} / \mathrm{h}\right)$ & 6,400 (installation included) & \\
\hline Labor & $\begin{array}{l}\text { 422 for Palermo, } 470 \text { for } \\
\text { Milan }\end{array}$ & \\
\hline Profit & & 26.5 \\
\hline Ordinary maintenance & & 1.5 \\
\hline $\begin{array}{l}\text { Extraordinary } \\
\text { maintenance }\end{array}$ & & 5 \\
\hline
\end{tabular}

As for the EAHX, considering that the case study is a new building, the excavation and refilling costs [6] are already present for the foundation works, thus they are evaluated as only $30 \%$ of the total ones. For labor and maintenance operation costs, the same values as for the AAHX are considered. The costs for the EAHX are reported in Table 7.

Table 7. Costs of the EAHX for Palermo and Milan

\begin{tabular}{|l|l|l|}
\hline & {$[€]$} & {$[\%]$} \\
\hline PVC duct & $2000\left(20 € \cdot \mathrm{m}^{-1}\right)$ & \\
\hline Installation & 400 & $20 \%$ \\
\hline $\begin{array}{l}\text { Excavation and } \\
\text { refilling }\end{array}$ & $1,600 * 0.3=480\left(10 € \mathrm{~m}^{-3}\right)$ & \\
\hline Labor & $\begin{array}{l}1,267 \text { for Palermo, } 1,410 \text { for } \\
\text { Milan }\end{array}$ & \\
\hline Profit & & 26.5 \\
\hline $\begin{array}{l}\text { Ordinary } \\
\text { maintenance }\end{array}$ & & 1.5 \\
\hline $\begin{array}{l}\text { Extraordinary } \\
\text { maintenance }\end{array}$ & & 10 \\
\hline
\end{tabular}

Once evaluated the initial investment, the discounted payback (DPB) is calculated for Palermo and Milan, considering the value of $0.245 € \cdot \mathrm{kWh}_{\mathrm{el}}{ }^{-1}$ obtained from Eurostat data [20].

As can be seen from the Figures 6 and 7, the DPB for the AAHX is equal to about 8.5 years for Palermo, less than 2 years for Milan. These values are reduced (5 years and less than 1 year, respectively) when considering an incentive of $20 \%$ of the initial investment cost, assumed in the first year.

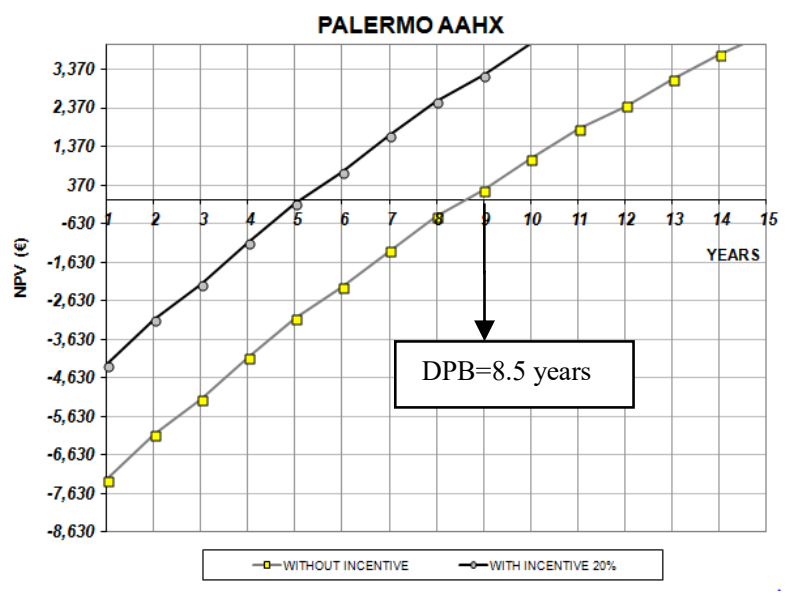

Figure 6. NPV and DPB, with and without incentive of $20 \%$, for the AAHX in Palermo 


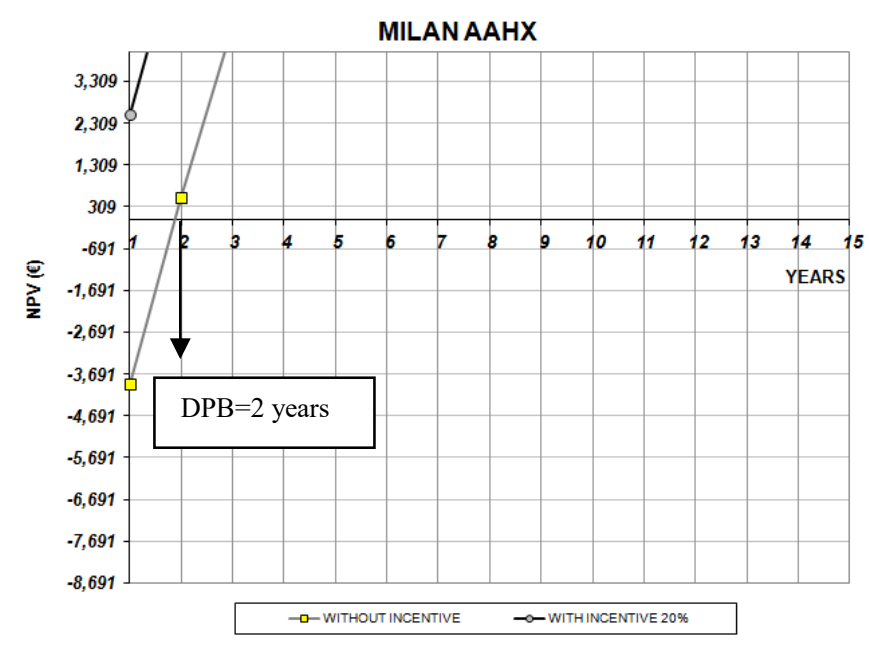

Figure 7. NPV and DPB, with and without incentive of $20 \%$, for the AAHX in Milan

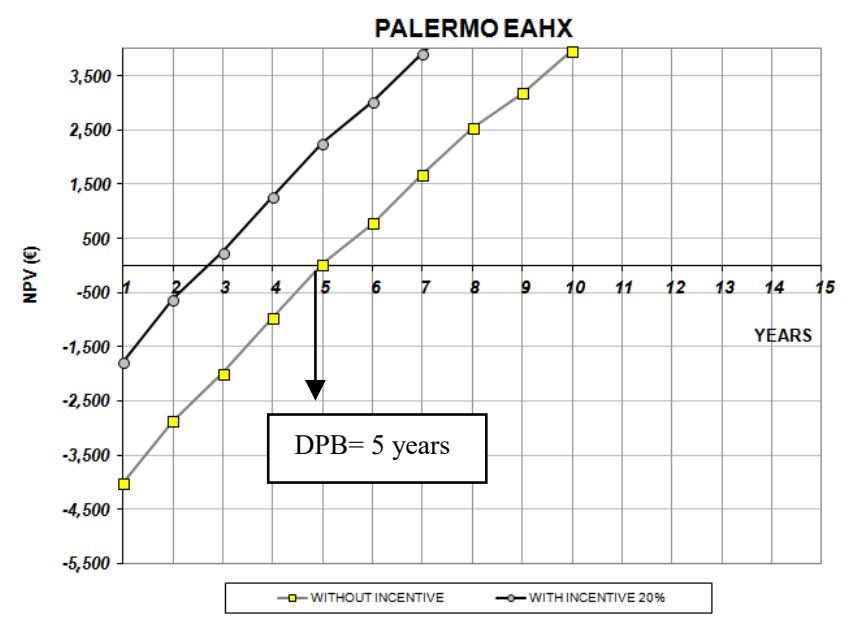

Figure 8. NPV and DPB, with and without incentive of $20 \%$, for the EAHX in Palermo

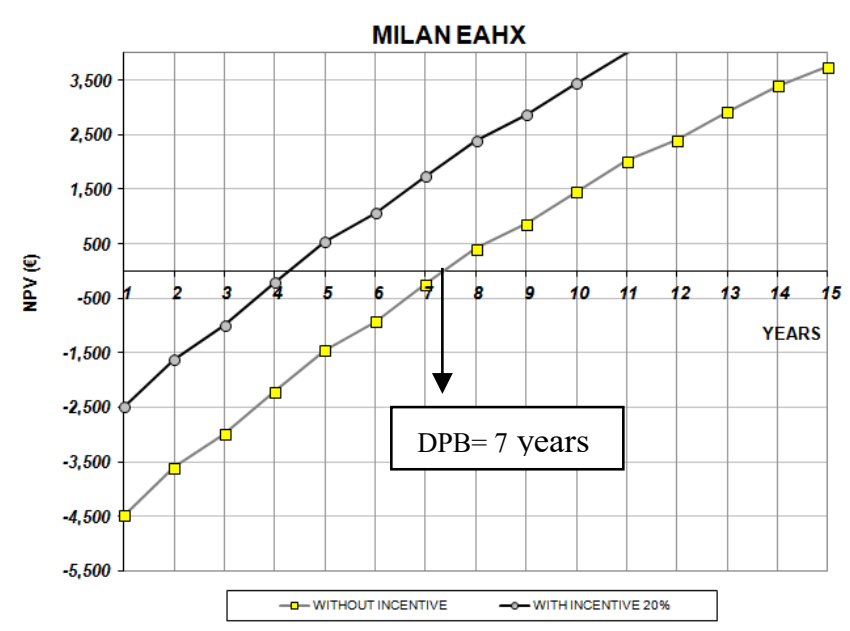

Figure 9. NPV and DPB, with and without incentive of $20 \%$, for the EAHX in Milan

The DPB for the EAHX is equal to 5 years for Palermo, about 7.5 years for Milan (Figures 8 and 9). Even in the case of EAHX, these values are reduced (about 2.5 years and 4 years, respectively) when considering an incentive of $20 \%$ of the initial investment cost.

These results are coherent with the energetic analysis. In fact, the energy analysis showed that, using separately the two technologies in continental climates like Milan, the AAHX leads to higher energy savings compared to EAHX. Conversely, the EAHX is more energy performing in hot climates (Palermo). Similar results derive also from the economic point of view. In fact, by installing the AAHX in Milan, not only an energy saving of 51\% compared to the EAHX is obtained, but also a DPB of only 2 years compared to 7 years relative to the use of the EAHX.

Conversely, the use of the EAHX for Palermo not only gets a greater percentage of energy savings compared to the AAHX, but also a DPB of 5 years instead of 8.5 years (relative to AAHX).

The energy-economic analysis is based on a number of variables, such as the cost of the heat exchangers and the price of electricity. In this regard, as the last step, a sensitivity analysis is performed to assess the variation of the DPB when changing the cost of the heat exchangers $( \pm 20 \%)$ and the price of electricity $( \pm 20 \%)$, as shown in the Table 8 . The results for Palermo are reported for both the AAHX (Figure 10) and EAHX (Figure 11). A higher influence of the electricity tariff on the DPB in the case of the AAHX is shown.

Table 8. Variation of the costs for the sensitivity analysis on the DPB

\begin{tabular}{|l|l|l|l|}
\hline & CASE STUDY & $(+20 \%)$ & $(-20 \%)$ \\
\hline $\begin{array}{l}\text { Electricity } \\
{\left[€ \cdot \mathrm{kWh}_{\mathrm{e}}{ }^{-1}\right]}\end{array}$ & 0.245 & 0.294 & 0.196 \\
\hline AAHX $[€]$ & 8,630 & 10,356 & 6,904 \\
\hline EAHX $[€]$ & 5,246 & 6,295 & 4,197 \\
\hline
\end{tabular}

PALERMO AAHX

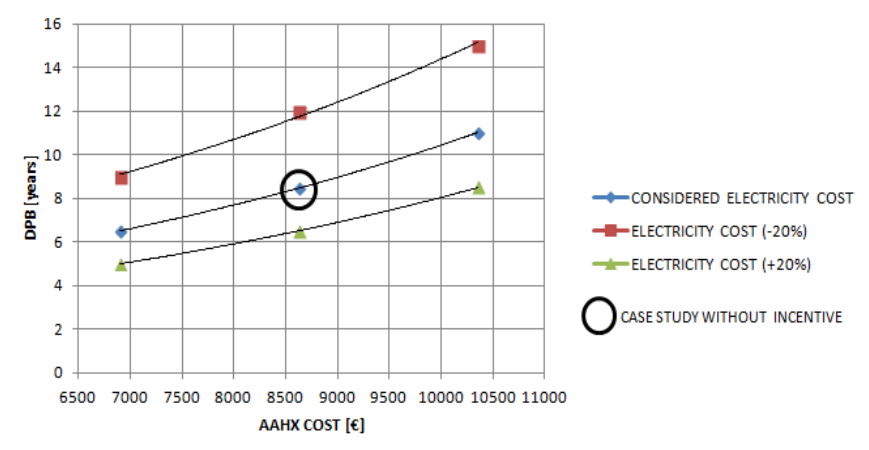

Figure 10. Sensivity analysis on the DPB when using the AAHX for Palermo

PALERMOEAHX

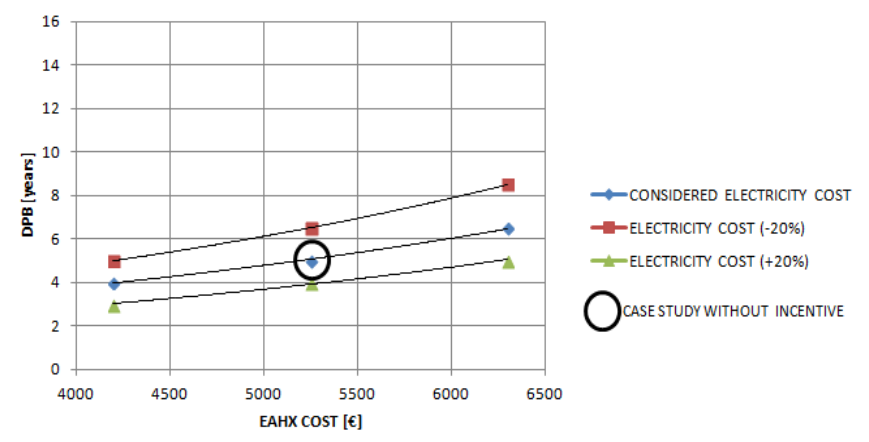

Figure 11. Sensivity analysis on the DPB when using the EAHX for Palermo 


\section{CONCLUSIONS}

This paper analyses two energy-efficient technologies, AAHX and EAHX, inserted alternatively in a common air conditioning system for two different Italian climates: Palermo, a city of Southern Italy characterized by hot summers and mild winters, and Milan, a city of Northern Italy characterized by hot summers and cold winters (continental climate). A case study is analyzed by means of dynamic building energy performance software, with reference to the same designed office building with or without the two types of heat exchangers. An energetic, environmental and economic analysis is performed.

When using alternatively the AAHX and the EAHX, the seasonal results show that the first type is more suitable in winter, particularly for Palermo (savings of 97\% compared to the reference case without any heat recovery), while the latter in summer, particularly in Milan (savings of $49 \%$ compared to the reference case).

In particular, in the hot-mild climate (Palermo), the energy demand for space heating is already low, so the only air-toair heat exchanger leads the energy demand to almost zero. This is important not only for the electric energy saving for heating, but also as an easy strategy to reduce the $\mathrm{CO}_{2 \text {-eq }}$ emissions (in fact, this a technology easy to be installed for both new buildings and retrofit of existing buildings).

Moreover, the yearly results show that the use of the AAHX is more suitable for Milan (yearly energy savings of $64 \%$ ) than for Palermo (28\%); on contrary, EAHX is more convenient for Palermo (savings of 30\%) than for Milan (13\%).

Based on the seasonal results, the two heat exchangers are coupled inside the HVAC system, using the AAHX in winter and the EAHX in summer. The results show that the coupling of the two technologies is more convenient for Milan (annual energy savings of $74 \%$ compared to the base case) than for Palermo (59\%). Moreover, the energy requirements for winter and summer air-conditioning purposes are reduced from $38 \mathrm{kWh}_{\mathrm{el}} \cdot \mathrm{m}^{-2}$ (reference case without any heat recovery) to $10 \mathrm{kWh}_{\mathrm{el}} \mathrm{m}^{-2}$ (coupled AAHX+EAHX) for Milan and from $22 \mathrm{kWh}_{\mathrm{el}} \cdot \mathrm{m}^{-2}$ to $8 \mathrm{kWh} \cdot \mathrm{m}^{-2}$ for Palermo. This shows that the coupling of the two heat recovery devices is very advantageous from an energy point of view, mainly for Milan. It can be noted that in this continental climate, the yearly energy requirements are significant (higher than for Palermo), so a considerable absolute energy saving is obtained.

The environmental analysis, in terms of annual carbon dioxide equivalent emissions, leads to results very similar to the energy investigation. The emission reduction related to the coupling of the AAHX and EAHX is equal to about 20 $\mathrm{kg}_{\mathrm{CO} 2 \text {-eq }} \cdot \mathrm{m}^{-2}$ for Milan and $9 \mathrm{~kg}_{\mathrm{CO} 2 \text {-eq }} \cdot \mathrm{m}^{-2}$ for Palermo, compared to the reference case. Thus, this strategy can reach the goal of drastically reducing polluting emissions, especially in cities like Milan, where pollution rates are very high.

Regarding the energetic-economic analysis, the results show that the discounted payback for the AAHX is equal to about 8.5 years for Palermo, just 2 years for Milan. These values are reduced ( 5 years and less than 1 year, respectively) when considering an incentive of $20 \%$ of the initial investment costs. The discounted payback is equal to 5 years for Palermo, about 7.5 years for Milan. These values are reduced to about 2.5 years and 4 years, respectively, when considering the incentive of $20 \%$. These results are coherent with the energetic and environmental analysis. Moreover, considering the case of Palermo, a higher influence of the electricity tariff on the discounted payback value for the AAHX is obtained.

\section{ACKNOWLEDGMENT}

This work was developed in the framework of the European project "Italian Training qualificatiOn Workforce in buildiNg" (Acronym: BUILD UP Skills I-TOWN), Intelligent Energy - Europe (IEE), Call for proposals CIPIEE-2013 - BUILD UP Skills Initiative. Contract $\mathrm{N}^{\circ}$ : IEE/13/BWI/721/SI2.680178.

\section{REFERENCES}

[1] Kamendere E., Zandeckis A., Kamenders A., Ikaunieks J. and Rochas C., "Analysis of mechanical ventilation system with heat recovery in renovated apartment buildings," Energy Procedia, vol. 72, pp. 27-33, 2015. DOI: 10.1016/j.egypro.2015.06.005.

[2] Akbari K. and Oman R., "Impacts of heat recovery ventilators on energy savings and indoor radon in a Swedish detached house," Management of Environmental Quality: An International Journal, vol. 24, no. 5, pp. 682-694, 2013. DOI: 10.1108/MEQ-062012-0050.

[3] Kamendere E., Zandeckis A., Kamenders A., Ikaunieks J. and Rochas C., "Mechanical ventilation with a heat recovery system in renovated apartment buildings," Agronomy Research, vol. 12, pp. 491-198, 2014.

[4] Koiv T. A., Mikola A. and Simson R., "Ventilation solutions in renovated apartment buildings in cold climate conditions," Scientific Research - Engineering, vol. 7, pp. 129-139, 2015. DOI: 10.4236/eng.2015.73011.

[5] http://www.rossatogroup.com/guide/pompe-dicalore/progettazione/111-come-funziona-un-impiantogeotermico.html (in Italian).

[6] Ascione F., Bellia L. and Minichiello F., "Earth-to-air heat exchangers for Italian climate," Renewable Energy, vol. 36, pp. 2177-2188, 2011. DOI: 10.1016/j.renene.2011.01.013.

[7] Santamouris M. and Asimakolpolus D., "Passive Cooling of Buildings," James \& James, 1996. https://books.google.it/books/about/Passive_Cooling_ of_Buildings.html?id=mEJSAAAAMAAJ\&redir_esc= $\mathrm{y}$

[8] Wienke U., "L'Edificio Passivo. Standard, Requisiti, Esempi," Alinea 2002. http://www.ibs.it/code/9788881256273/wienkeuwe/edificio-passivo-standard.html (in Italian).

[9] Khadrawi A.F., Balabel A. and Al-Osaimy Ali S., "A new cooling technique using phase change material in a car ceiling and wall buildings," International Journal of Heat and Technology, vol. 32, no. 1, pp. 185190, January 2014.

[10] U.S. Deparment of energy. DesignBuilder 3.2.0.67

[11] U.S. Deparment of energy. EnergyPlus 7.2.0.006 
[12] Olsen, E. L. and Chen, Q. Y., "Energy consumption and comfort analysis for different low-energy cooling systems in a mild climate," Energy and Buildings, vol. 35, pp. 560-571, 2003. DOI: 10.1016/S03787788(02)00164-0.

[13] U.S. Department of Energy. EnergyPlus Testing with HVAC Equipment Performance Tests from ANSI/ASHRAE Standard 140-2011, pp. 1-80, 2011. http://apps1.eere.energy.gov/buildings/energyplus/ener gyplus_testing.cfm.

[14] U.S. Department of Energy. EnergyPlus Testing with Building Thermal Envelope and Fabric Load Tests from ANSI/ASHRAE Standard 140-2011, 2011, 1-32. http://apps1.eere.energy.gov/buildings/energyplus/ener gyplus testing.cfm.

[15] Bensenouci A., Benchatti A., Bounif A. and Medjelledi A., "Study of the energy efficiency in building house using the DOE-2E and EE4 softwares simulation," International Journal of Heat and Technology, vol. 27, no. 2, pp. 57-63, 2009.

[16] ASHRAE. International Weather files for Energy Calculations (IWEC weather files). User's manual and CD-ROM, American Society of Heating, Refrigerating and Air-Conditioning Engineers, Atlanta, GA, USA, 2001.

[17] EUROVENT Heat recovery devices: specifications, terminology, classification and functional characteristics, EUROVENT REC 10-1, 1986.

[18] ANCE (Associazione Nazionale Costruttori Edili), "Rilevazione costo del salario orario nella provincia di Palermo settore edile," 2015 (in Italian).

[19] ANCE (Associazione Nazionale Costruttori Edili), "Costi orari della manodopera edile per tutti i comuni delle province di Milano, Lodi, Monza e Brianza," 2015 (in Italian).

[20] Eurostat (2015), "Energy price statistics," [Online]. Available:

http://ec.europa.eu/eurostat/statisticsexplained/index.p hp/Energy_price_statistics\#Electricity_prices_for_hou sehold_consumers.

\section{NOMENCLATURE}

AAHX
AHU
CDD
DPB
EAHX
HDD
HVAC
NPV
SCOP
SEER
U

\section{Subscripts}

el electric

eq equivalent
Air-to-Air Heat Exchanger

Air Handling Unit

Cooling Degrees-Day, K'day

Discounted PayBack, number of years

Earth-to-Air Heat Exchanger

Heating Degrees-Day, K·day

Heating Ventilation and Air Conditioning

Net Present Value, Euro

Seasonal Coefficient of Performance

Seasonal Energy Efficiency Ratio

Unitary thermal transmittance, $\mathrm{W} \cdot \mathrm{m}^{-2} \cdot \mathrm{K}^{-1}$ 